\title{
PRIKAZ SUSTAVA ZA UPRAVLJANJE INFORMACIJAMA NA AUTOCESTAMA POMOĆU DIJAGRAMA
}

\author{
Josip Jerčić \\ Bacc. ing. traff., Ceste Rijeka d. o. o., Kukuljanovo 377, 51223 Škrljevo, Hrvatska; \\ e-mail: jercicjosip@gmail.com \\ Mirta Mataija
}

Mr. sc., pred., Veleučilište u Rijeci, Trpimirova 2/V, 51000 Rijeka, Hrvatska; e-mail: mirta.mataija@veleri.hr

\section{SAŽETAK}

Autoceste u Republici Hrvatskoj opremljene su najmodernijim sustavima za upravljanje i kontrolu prometa. Sustav nadzora i upravljanja prometom na autocestama provodi se konstantno 24 sata na dan iz centara za održavanje i kontrolu prometa koji se nalaze uz pojedine dionice autocesta. Centri za kontrolu prometa na autocestama uz uporabu modernih inteligentnih transportnih sustava konstantno i u realnom vremenu nadziru stanje na autocestama te uz pomoć razvijenih modernih informatičkih sustava upozoravaju i pripremaju korisnike autocesta na sve izvanredne situacije na koje bi mogli naići. Uz pomoć kamera i sustava videonadzora razmještenog po autocestama operateri imaju uvid u trenutno stanje na dionici na autocesti prvenstveno pomoću kamera za detekciju prometnih nesreća, vožnje u suprotnom smjeru, zastoja na prometnici i sl. Brojne meteorološke postaje uzduž autocesta također prikupljaju i obrađuju podatke vezane uz vremenske prilike na autocesti te korisnike autocesta upozoravaju na sve moguće vremenske uvjete koji se očekuju na njoj. U radu je sustav upravljanja informacijama na autocestama opisan dijagramom. Na taj način prikazan je tijek informacija ključnih za povećanje sigurnosti i rješavanje problema emisija i zagušenja. Prikaz tijeka informacija između sustava senzora s jedne strane, operatera u centrima za održavanje $i$ kontrolu prometa s druge te sustava promjenjivih znakova s treće strane dan je pomoću dijagrama. Pravodobno informiranje sudionika u prometu o promjenjivim meteorološkim uvjetima putem promjenjivih znakova od presudnog je značaja za sigurno odvijanje prometa na autocestama.

Ključne riječi: autocesta, centar za održivu kontrolu prometa, cestovna prometna stanica, sigurnost prometa, upravljanje prometom 


\section{UVOD}

Politika Europske unije prema cestovnom prometu potiče promicanje mobilnosti koja je učinkovita, sigurna i ekološki prihvatljiva (eur-lex.europa.eu). Inteligentni transportni sustavi (ITS) (ec.europa. eu) od vitalnog su značaja za povećanje sigurnosti i rješavanje sve većih problema emisija i zagušenja Europe. ITS mogu učiniti prijevoz sigurnijim, učinkovitijim i održivijim primjenom različitih alata ITtehnologije. Već danas je vidljiva značajna primjena ITS-a, a u nadolazećim godinama za očekivati je da će digitalizacijom prijevoza i još većom primjenom ITS-a cestovni promet napraviti velik korak naprijed.

Autoceste u Republici Hrvatskoj su javne ceste s tehničkim karakteristikama određenim propisima kojima seuređuje sigurnost prometa na cestama koje imaju funkciju povezivanja RepublikeHrvatske u europski prometni sustav, ostvarivanja kontinuiteta e-ceste (međunarodnim i međudržavnim sporazumima određene kao europske ceste), prometnog povezivanja regija Republike Hrvatske, omogućavanja tranzitnog prometa, a koje su razvrstane kao autoceste sukladno Zakonu o cestama Republike Hrvatske. Građenje autocesta u Republici Hrvatskoj započelo je izgradnjom dionice Zagreb - Karlovac dužine 40 kilometara, koja je dovršena potkraj 1972. godine (Hrvatske autoceste d. o. o., HAC, 2006).

Slika 1. Mreža autocesta u RH i koncesionari

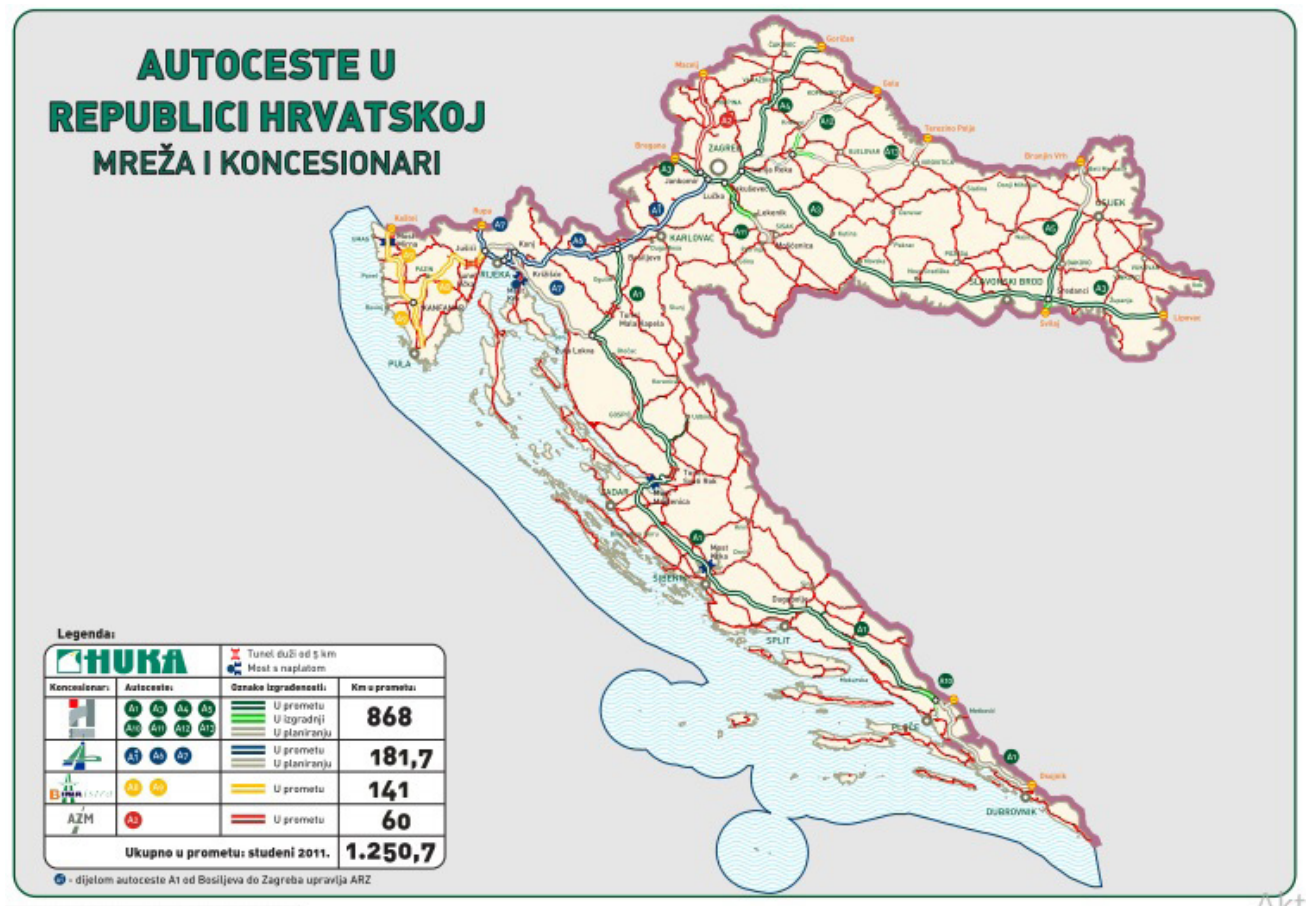

Izvor: http://www.huka.hr/mreza-autocesta

Hrvatske autoceste danas se označavaju velikim slovom A i brojčanom oznakom iza slova. Mreža autocesta i poluautocesta s naplatom iznosi ukupno 1.301,6 km (stanje 31. prosinca 2013.), a 
njima upravljaju i gospodare četiri koncesionara, dok je brzina na njima ograničena na $130 \mathrm{~km} / \mathrm{h}$. Hrvatske autoceste upravljaju s 900,5 km, Autocesta Rijeka - Zagreb s 187 km, Bina - Istra s 141 km, a koncesionar Autocesta Zagreb - Macelj sa $60 \mathrm{~km}$ autocesta pod naplatom (www.huka.hr).

\section{PRIMJENA ITS-A NA AUTOCESTAMA U RH}

Cestovna povezanost u RH posljednjih nekoliko desetljeća znatno je poboljšana, a jedan od uzroka svakako je ulaganje u izgradnju suvremenih autocesta na području $\mathrm{RH}$, čime se cestovna prometna mreža RH pozicionirala među najbolje na svijetu. Hrvatske autoceste svojevremeno su prilikom izgradnje koristile najsuvremenija dostignuća na području ITS-a, što dokazuju EuroTAP istraživački projekti o sigurnosti tunela u kojima su Hrvatske autoceste redovito ocjenjivane najvišim ocjenama (www.hak.hr). Za normalno funkcioniranje prometa na autocestama bilo je nužno uspostaviti sustave za razmjenu informacija, odnosno IT-sustave. Oni su podijeljeni u dvije skupine (Autoceste u Republici Hrvatskoj, HAC, 2006):

1. Informacijski sustav autocesta koji obuhvaća prometni informacijski sustav, sustav daljinskog vođenja (samo u tunelima), sustav videonadzora autoceste, sustav videodetekcije i sustav naplate.

2. Komunikacijski sustav autocesta koji obuhvaća telefonsko-pozivni sustav, sustav ozvučenja tunela i sustav radiofuzije u tunelu. Uređaji prometnog informacijskog sustava koji se postavljaju neposredno uz autocestu su: stanice sustava videodetekcije, meteorološke mjerne stanice, promjenjivi prometni znakovi (svjetlosni i elektromehanički), semafori te signali prometnog traka.

Upravljanje i kontrola prometa na autocestama na pojedinim dionicama ili na razini cijele mreže autocesta Republike Hrvatske obavlja se u Centrima za održavanje i kontrolu prometa u kojima se pomoću računala svi bitni podatci koji se dobivaju prikupljanjem podataka na autocestama obrađuju. Pomoću senzora, meteoroloških stanica i kamera u realnom vremenu zaprimaju se i obrađuju svi bitni podatci, uz čiju pomoć operateri iz COPK-a pravodobno upozoravaju korisnike autocesta na sve potencijalne opasnosti. 


\section{1 Centar za održavanje i kontrolu prometa}

Slika 2. Unutrašnjost COKP-a s prometnom stanicom i pregledom kamera

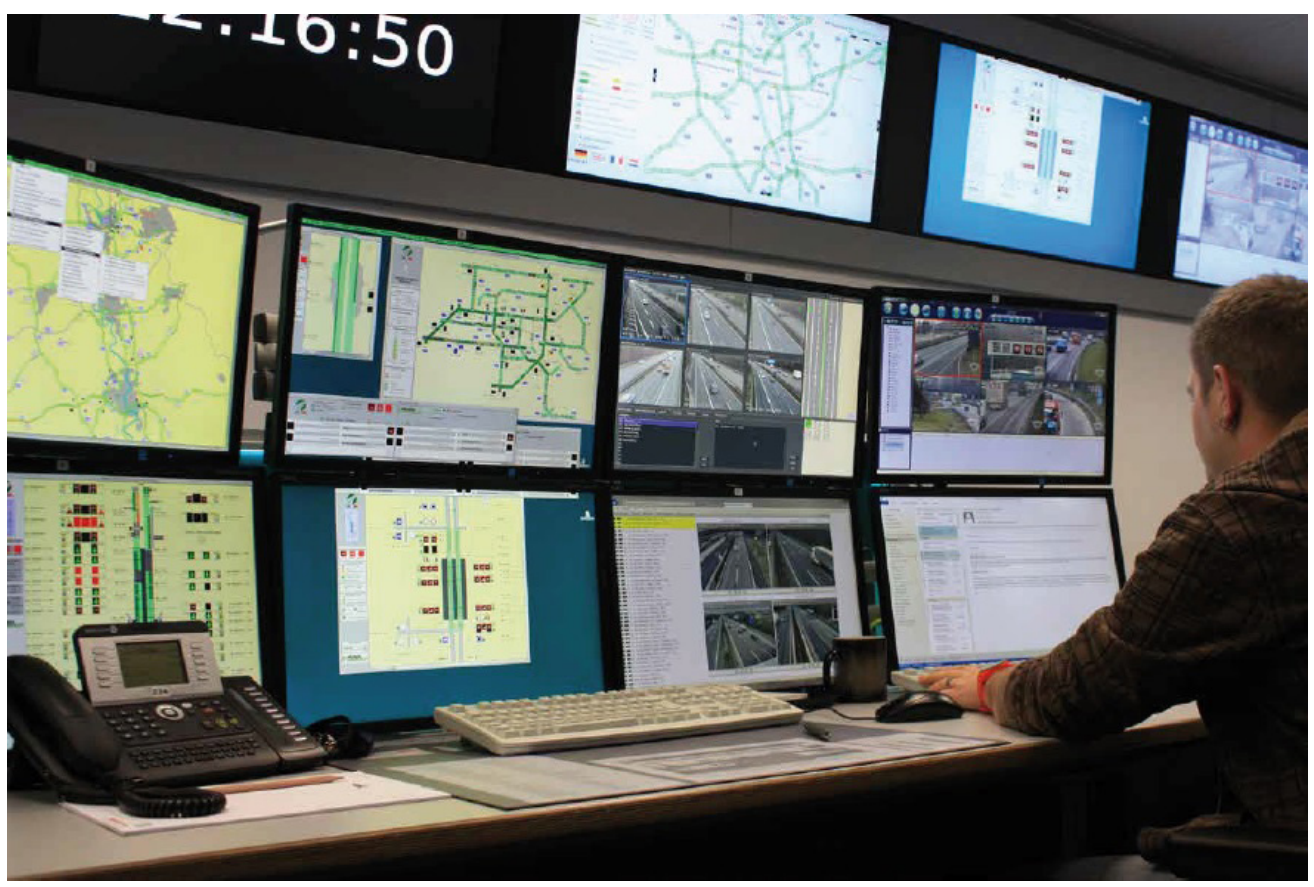

Izvor: Das Verkehrssicherheitsprogramm Nordrhein-Westfalen, 2020:85. (12. 12. 2018.)

Centar za održavanje i kontrolu prometa najbitniji je cestarski objekt. Unutar Centra za održavanje i kontrolu prometa nalazi se sva mehanizacija potrebna za održavanje autocesta, kao i ljudstvo koje je spremno u svakom trenutku djelovati na bilo kakvu neželjenu situaciju na autocesti. No, najbitniji dio svakog COKP-a je posebno tehničko odjeljenje koje se bavi prikupljanjem i obradom podataka prikupljenih na autocesti. Svi podatci iz senzora postavljenih na autocesti prikazani su u realnom vremenu na videozidovima unutar COKP-a. Svaki COKP posjeduje sustav središnjeg upravljanja prometom koji se sastoji od nekoliko komponenti (Mandžuka, 2010; Bošnjak, 2006):

- $\quad$ prometne centrale

- $\quad$ prometne radne stanice

- podsustava za kratkoročnu prognozu vremenskih uvjeta na prometnicama

- $\quad$ podsustava za videonadzor.

U COKP-u se obično nalazi nekoliko centralnih jedinica kao što su: telekomunikacijska centrala, centrala za kontrolu rasvjete, ventilacije, vatrodojavna centrala, centrala za videonadzor i sl. 
Dijagram 1. Sustavi centra za održavanje i kontrolu prometa

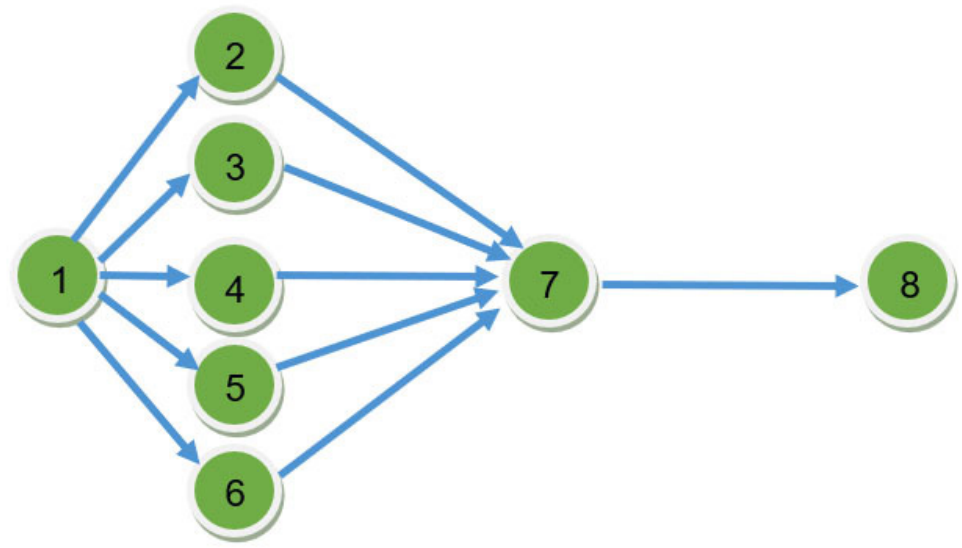

Izvor: obrada autora

1. Senzor

2. Telekomunikacijska centrala

3. Centrala za kontrolu rasvjete

4. Centrala za kontrolu ventilacije

5. Vatrodojavna centrala

6. Centrala za videonadzor

7. Centar za održavanje i kontrolu prometa

8. Reakcija

\section{2 Prometna centrala}

Prometna centrala je računalo za rad u realnom vremenu koje se nalazi unutar tehničkog odjela COKP-a. Računalo pomoću instaliranog operacijskog sustava služi za obradu prikupljenih podatka iz senzora s cestovnih prometnih stanica i prosljeđivanje naredbi cestovnim prometnim stanicama za upravljanje promjenjivim prometnim znakovima, nakon što se dobiveni podatci obrade u COKP-u. Veza prometne centrale i cestovne prometne stanice ostvaruje se po određenom protokolu. Na temelju prikupljenih podataka o uvjetima na autocesti te podataka s ostalih senzora s cestovnih prometnih stanica, prometna centrala stvara bazu podataka. 
Dijagram 2. Tijek informacija preko prometne centrale

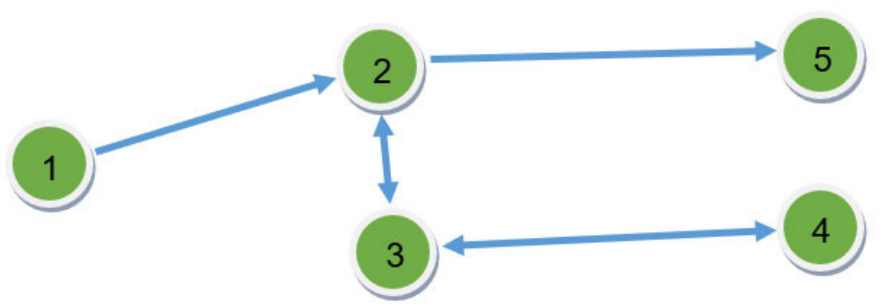

Izvor: obrada autora

1. Senzor

2. Cestovna prometna stanica

3. Prometna centrala

4. Centar za održavanje i kontrolu prometa

5. Reakcija

\section{3 Cestovna prometna stanica}

Cestovna prometna stanica lokalno je postavljeno računalo za obradu podataka o meteorološkim podatcima i podatcima o prometu koje potom prikupljene podatke šalje u prometnu centralu unutar COKP-a na daljnju obradu. Pomoću CPS-a se na dionici autoceste također upravlja promjenjivim prometnim znakovima (www.jpautoceste.ba). U slučaju da dođe do prekida veze između prometne centrale i cestovne prometne stanice, one prelaze $u$ automatski način rada. $U$ slučaju alarmnog događaja CPS prelazi u siguran način rada, čime se pokreću algoritmi za rješavanje novonastale situacije bez čekanja na djelovanje operatera. 
Dijagram 3. Tijek informacija do određenog upozorenja

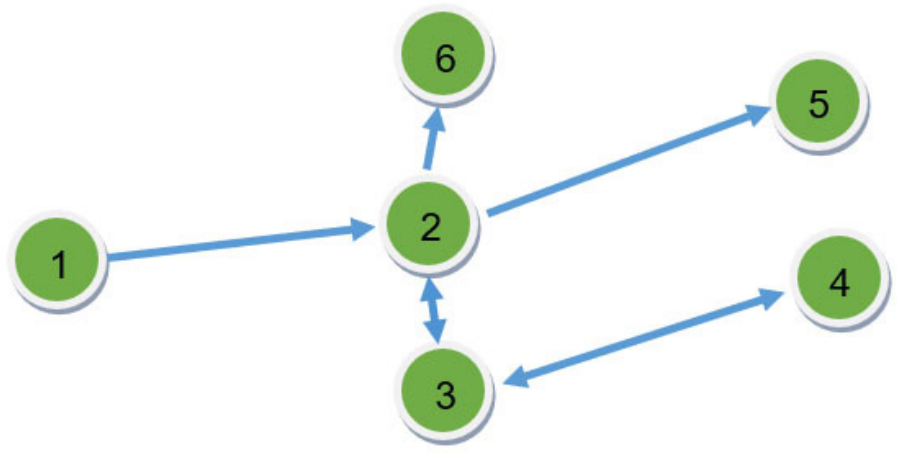

Izvor: obrada autora

1. Senzor

2. Cestovna prometna stanica

3. Prometna centrala

4. Centar za održavanje i kontrolu prometa

5. Promjenjivi prometni znakovi

6. Rampe

Slika 3. Primjer upravljanja promjenjivom prometnom signalizacijom na autocesti

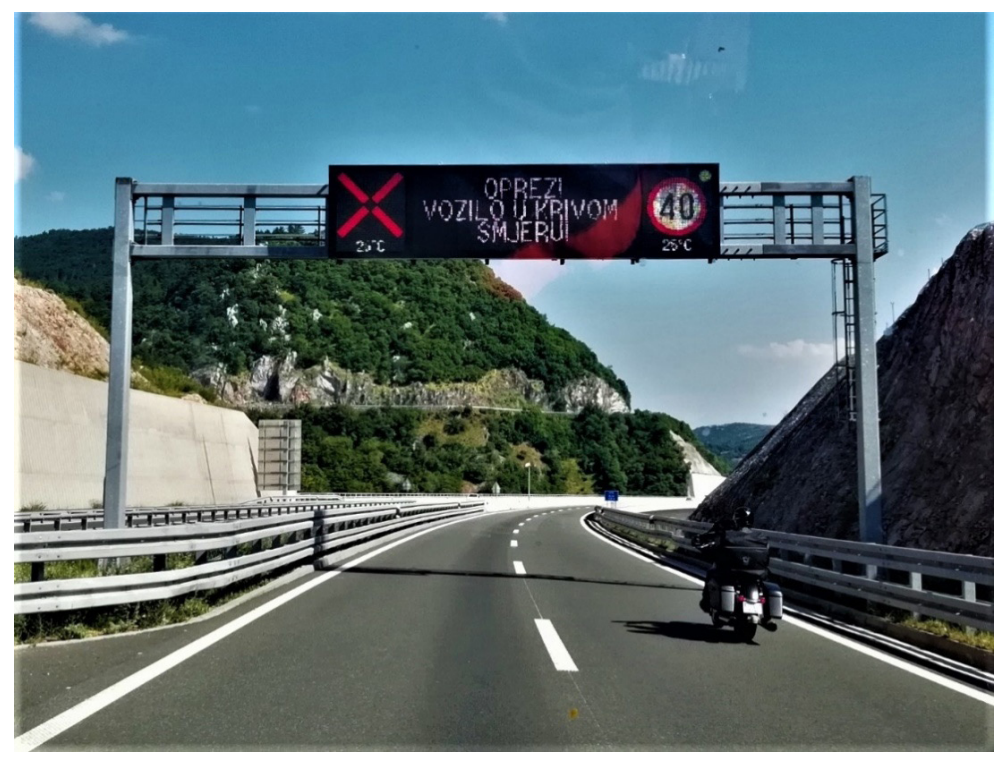

Izvor: obrada autora 
Slika 4. Primjeri promjenjive prometne signalizacije na autocesti

\section{0) Ograničenje brzine}

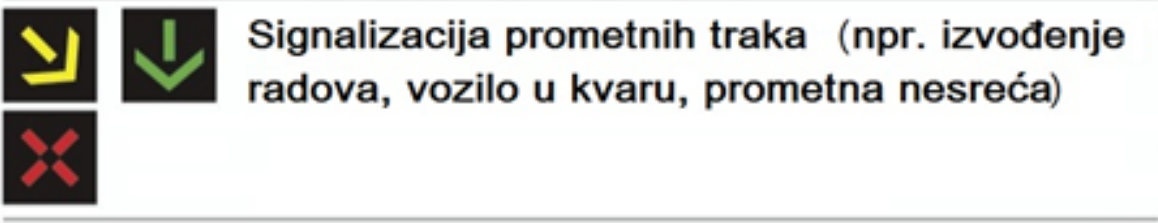

\section{(1) \\ A}

Upozorenje o opasnosti na autocesti

(npr.poledica, sklizak kolnik, jak vjetar)

11

\section{Opasnost na cesti i kolona vozila (npr. prometne nesreće i sl.)}

Izvor: https://svn.vsp.tu-berlin.de/repos/public-svn/lehre/veranstaltungen/ss_2011/0533_I_050/telematik.pdf(12.

12. 2018.)

\section{TIJEK METEOROLOŠKIH PODATAKA I PODATAKA U TUNELIMA NA AUTOCESTAMA}

Sigurno odvijanje prometa na cestama i autocestama uvelike ovisi o vremenskim prilikama i neprilikama. Za sve korisnike autocesta bitne su točne i pravovremene informacije o meteorološkim uvjetima bitnima za vožnju. Cestovne meteorološke postaje su mjerni uređaji postavljeni na autocestama, a služe prikupljanju važnih parametara o trenutnom stanju na prometnicama kao što su: količina oborine, brzina vjetra, temperature kolnika i zraka, tlaka i vlažnosti zraka. Tuneli na autocestama svom su svojom dužinom prekriveni nadzornim kamerama, ali i mnoštvom drugih senzora bitnih za sigurno odvijanje prometa. Na ulazima i izlazima iz tunela ugrađuju su mjerači intenziteta svjetlosti koji služe za određivanje rasvjete u prilagodnim zonama, a bitan dio za sigurnost prometovanja kroz tunele su vatrodojavni alarmi te nadzorne kamere za konstantni nadzor vozila koja se kreću kroz tunele.

\section{1 Tijek meteoroloških podataka}

Cestovne meteorološke postaje pomoću ugrađenih senzora otkrivaju i analiziraju potencijalno opasne situacije na cesti (oborine, poledica, jak vjetar...), te dobivene podatke $s$ autoceste šalju u COKP, odakle se postavljaju upozorenja na promjenljive znakove. U zimskom periodu podatci prikupljeni na cestovnim meteorološkim stanicama pomažu službama za održavanje i gospodarenje cesta u odlučivanju vezanom za pravilno tretiranje prometnica. 
Podatci s meteoroloških postaja su trenutni te se mogu koristiti za pravovremeno reagiranje u opasnim situacijama.

Dijagram 4: Tijek meteoroloških podataka

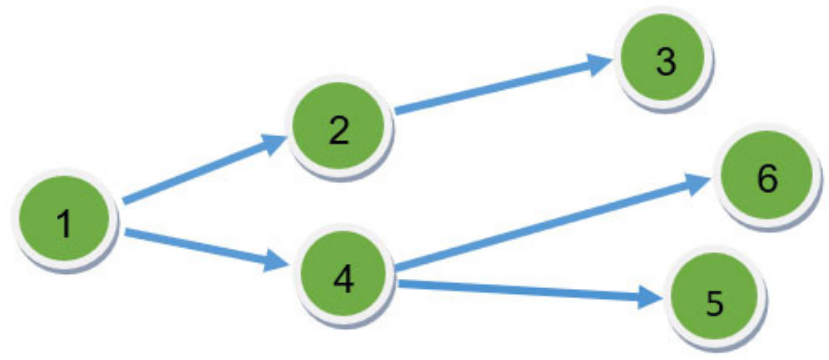

Izvor: obrada autora

1. Meteorološka postaja

2. Računalo

3. Internet

4. Centar za održavanje i kontrolu prometa

5. Svjetlosni znakovi

6. Održavanje prometnice (npr. posipanje soli zbog moguće poledice)

Meteorološke stanice vrlo su bitne na autocestama, naročito u uvjetima lošeg vremena (kiša, snijeg, magla, poledica, jak vjetar) radi izbjegavanja incidentnih situacija, kada operater u COKP-u uz pomoć prikupljenih podataka s meteoroloških postaja obavještava pravovremeno korisnike autocesta o trenutnim uvjetima na cesti s pomoću promjenjivih prometnih znakova.

Tablica 1. Parametri za zatvaranje cesta za pojedine skupine vozila u uvjetima jakog vjetra

\begin{tabular}{|c|c|c|c|}
\hline & Suh kolnik & Sklizak kolnik & Zaleđen kolnik \\
\hline $\begin{array}{l}\text { skupina vozila (autobusi na kat, vozila s } \\
\text { kamp-prikolicama, motocikli }\end{array}$ & $\begin{array}{l}\text { Brzina vjetra > } \\
60 \mathrm{~km} / \mathrm{h}\end{array}$ & $\begin{array}{l}\text { Brzina vjetra > } \\
50 \mathrm{~km} / \mathrm{h}\end{array}$ & $\begin{array}{l}\text { Brzina vjetra > } \\
20 \mathrm{~km} / \mathrm{h}\end{array}$ \\
\hline $\begin{array}{l}\text { skupina vozila (dostavna vozila i vozila s } \\
\text { natkrivenim teretnim prostorom) }\end{array}$ & $\begin{array}{l}\text { Brzina vjetra > } \\
90 \mathrm{~km} / \mathrm{h}\end{array}$ & $\begin{array}{l}\text { Brzina vjetra > } \\
70 \mathrm{~km} / \mathrm{h}\end{array}$ & $\begin{array}{l}\text { Brzina vjetra > } \\
25 \mathrm{~km} / \mathrm{h}\end{array}$ \\
\hline $\begin{array}{l}\text { skupina vozila (cesta otvorena samo za } \\
\text { osobna vozila) }\end{array}$ & $\begin{array}{l}\text { Brzina vjetra > } \\
110 \mathrm{~km} / \mathrm{h}\end{array}$ & $\begin{array}{l}\text { Brzina vjetra > } \\
90 \mathrm{~km} / \mathrm{h}\end{array}$ & $\begin{array}{l}\text { Brzina vjetra > } \\
30 \mathrm{~km} / \mathrm{h}\end{array}$ \\
\hline
\end{tabular}


Slika 5. Meteorološka postaja na autocesti

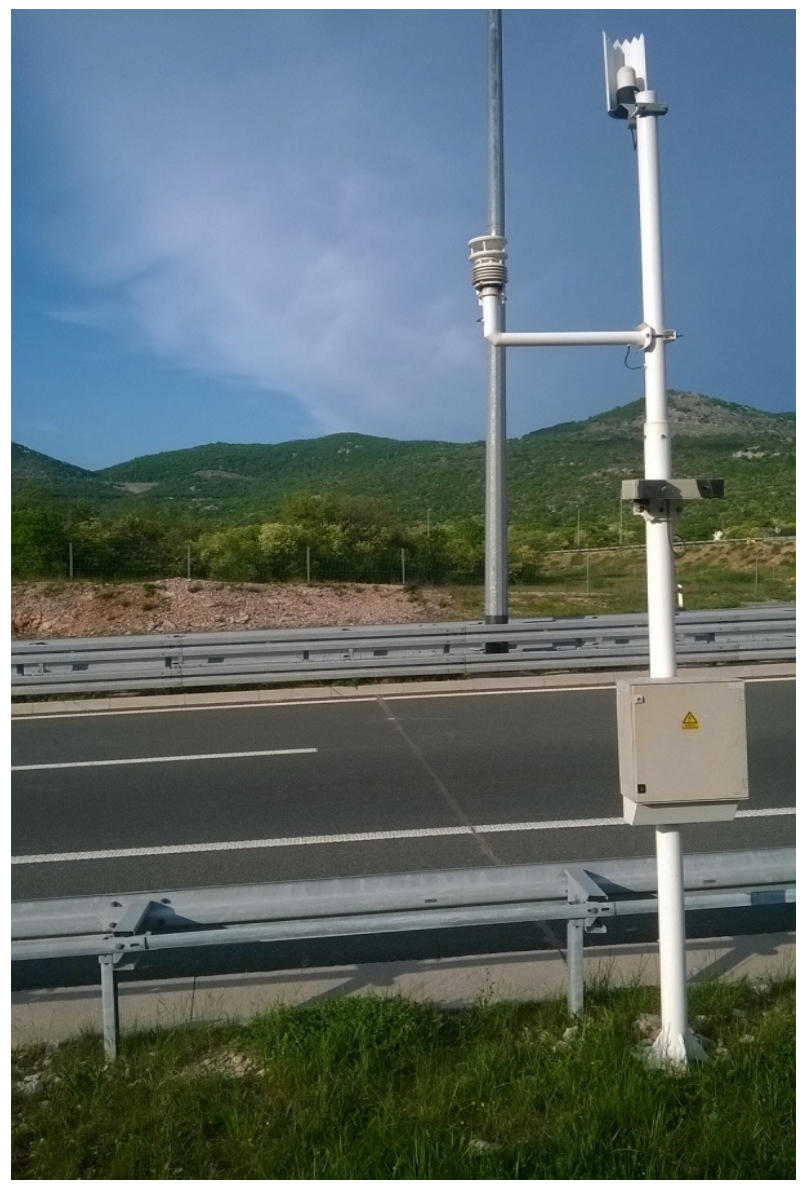

Izvor: obrada autora

Na mikrolokaciji meteorološke postaje mjere se (www.prometna-signalizacija.com):

\section{Meteorološki podatci:}

- temperatura, relativna vlažnost zraka i temperatura rosišta

- brzina i smjer vjetra

- tlak zraka

- količina, intenzitet i vrsta padalina

- vidljivost.

2. Kolnička osjetila mjere: 
- $\quad$ stanje vlažnosti površine kolnika

- temperaturu površine unutrašnjosti kolnika

- $\quad$ koncentracije soli na površini kolnika

- $\quad$ prisutnost poledice, leda, mraza ili smrznutog snijega.

Centralni mikroprocesorski uređaj prikuplja i obrađuje podatke s mjernih sondi i na osnovi toga daje sljedeće signale:

- izračunatu točku smrzavanja na kolniku

- potrebnu količinu sredstava za odleđivanje kolnika

- $\quad$ upozorenje i alarm povećanog rizika od prisutnosti poledice, leda ili snijega.

\subsection{Informacijski sustavi u tunelima}

Informacije prikupljene na senzorima jačine svijetla, koji se nalaze ispred tunela duljine 500 metara i više (www.enciklopedija.hr), ulaze u tunel i rasvjetljavaju različito od sredine tunela, kako bi se oči vozača stigle priviknuti na razliku. Snaga svjetla u tunelu ovisi o dobi dana i vremenskim uvjetima koji utječu na količinu vanjske svjetlosti. Prilagodnu rasvjetu moraju imati svi tuneli, pa tako i najmanji.

Slika 6. Mjerač intenziteta svjetlosti ispred tunela

Slika 7. Senzori unutar tunela
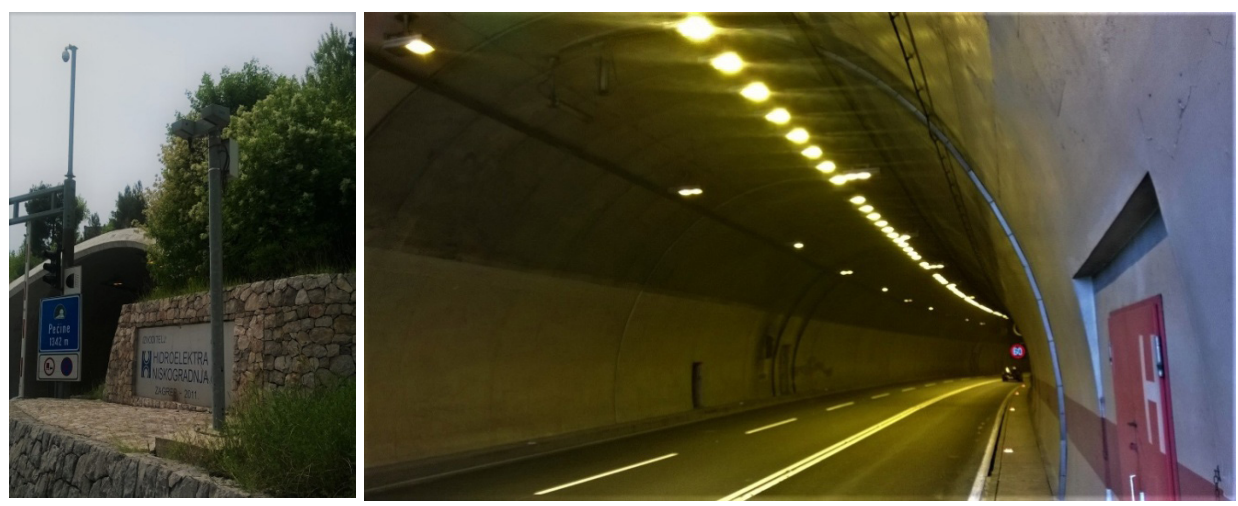

Izvor: obrada autora

Vatrodojavni sustav u tunelima nadzire se pomoću temperaturnog kabela koji reagira na razliku porasta temperature u požarnim zonama na koje je podijeljen svaki tunel, a to znači da, ako je razlika u temperaturi veća od podešene, automatski dolazi do paljenja općeg alarma. Do paljenja alarma dolazi i u drugim slučajevima, kao što je zaustavljanje vozila u tunelu ili vožnja u suprotnom smjeru. Nakon toga se po protokolu pale semafori ispred tunela, a brzina se na ulazima i kroz tunel smanjuje (www.prometna-signalizacija.com). 
Dljagram 5: Tijek informacija prilikom požara u tunelima

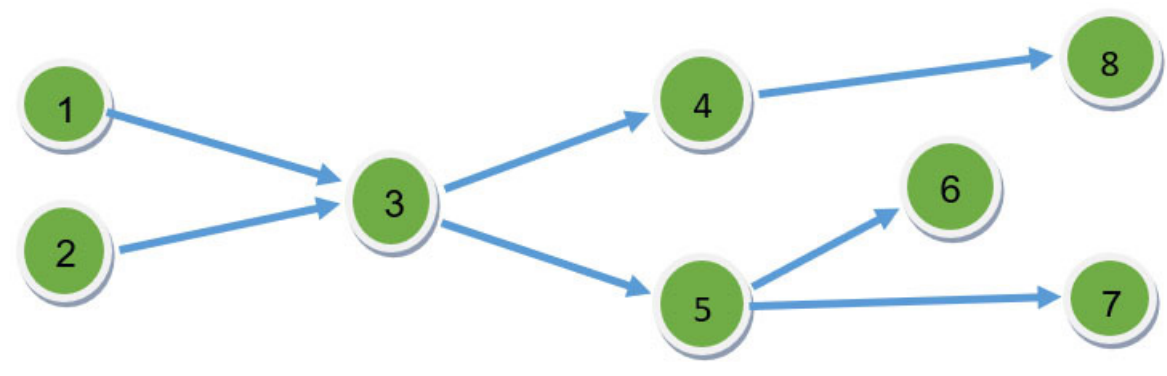

Izvor: obrada autora

1. Razlika u porastu temperature

2. Razlika u požarnim zonama

3. Alarm

4. Centar za održavanje i kontrolu prometa

5. Cestovna prometna stanica

6. Paljenje semafora ispred tunela

7. Smanjenje ograničenja brzine

8. Reakcija (npr. obavještavanje vatrogasaca)

Procedura postoji za praktički sve situacije; protupožarni aparati, primjerice, nadzirani su magnetnim relejima te se po njihovu podizanju uključuje alarm. Ako se vrati na svoje mjesto u roku od 45 sekundi, automatski se isključuje.

Slika 8. Semafori na ulazu u tunel

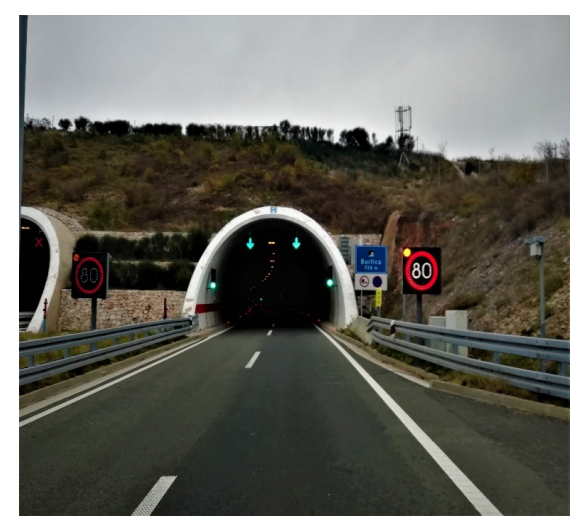

Izvor: obrada autora 
Slika 9. Odašiljači radijskog i telefonskog signala u tunelu

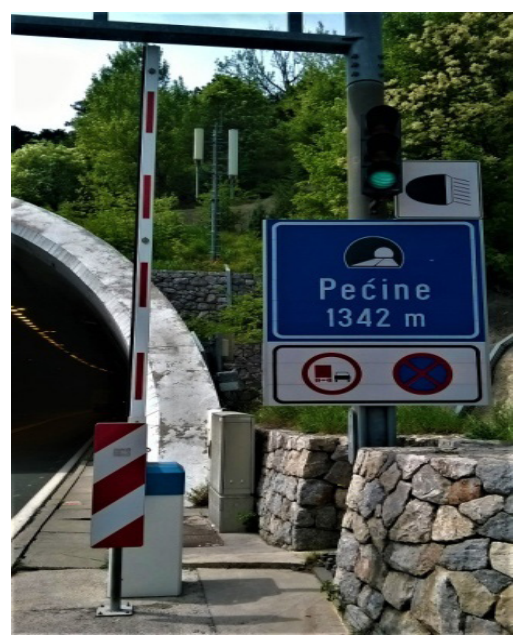

Izvor: obrada autora

\section{ZAKLJUČAK}

Autoceste na prostoru Republike Hrvatske opremljene su modernim sustavima za kontrolu prometa koji su definitivno zaslužni za to što su pojedine dionice autocesta u Republici Hrvatskoj ocjenjivane jako dobro. Vrlo bitna stavka za buduća razdoblja je da se hrvatske autoceste redovito održavaju i da se informacijski sustavi konstantno osuvremenjuju najnovijim tehničkim i tehnološkim dostignućima, kako bi hrvatske autoceste i u budućim razdobljima zadovoljavale najstrože kriterije sigurnosti i kako bi se korisnike autocesta i ubuduće zadovoljilo na najvišem nivou. Bitna stavka u pravilnom korištenju informacijskih sustava je i čovjek, koji informacijskim sustavima na autocestama upravlja i koji vozače i ostale korisnike mora pravodobno informirati najsvježijim prikupljenim informacijama, naročito $u$ izvanrednim situacijama na cesti, te pravovremeno reagirati da se izbjegnu sve potencijalno opasne situacije.

\section{LITERATURA}

Autoceste u Republici Hrvatskoj (2006), Zagreb: HAC

Bošnjak, I. (2006), Inteligentni transportni sustavi - ITS 1, Zagreb: FPZ

Das Verkehrssicherheitsprogramm Nordrhein-Westfalen 2020 (2018), Düsseldorf: Ministerium für Verkehr des Landes Nordrhein-Westfalen, ec.europa.eu/transport/themes/its_en (15. prosinca 2018.)

Hrvatske autoceste (2006), Zagreb: HAC

Mandžuka, S. (2010), Inteligentni transportni sustavi - ITS 2, Zagreb: FPZ

eur-lex.europa.eu/LexUriServ/LexUriServ.do?uri=OJ:L:2010:207:0001:0013:EN:PDF (13. 12. 2018.)

www.enciklopedija.hr/Natuknica.aspx?ID=62681 (7. 2. 2019.) 
J. Jerčić, M. Mataija: Prikaz sustava za upravljanje informacijama na autocestama pomoću dijagrama Zbornik Veleučilišta u Rijeci, Vol. 7 (2019), No. 1, pp. 393-407

www.hak.hr/sigurnost-u-prometu/projekti/eurotap (14. 12. 2018.)

www.huka.hr/mreza-autocesta (30.11. 2018.)

www.jpautoceste.ba/cestovne-prometne-stanice-i-podstanice-cps-i-cpps/ (13. 12. 2018.)

www.prometna-signalizacija.com/informacijsko-komunikacijski-sustavi-u-prometu/cestovne-meteroloskestanice/ (18. 12. 2018.)

www.prometna-signalizacija.com/informacijsko-komunikacijski-sustavi-u-prometu/sustavi-vatrodojave-ucestovnim-tunelima/ (13. 12. 2018.)

www.prometna-signalizacija.com/informacijsko-komunikacijski-sustavi-u-prometu/sustavi-za-nadzor-tunela/ (18. 12. 2018.)

www.prometna-signalizacija.com/oprema-ceste/oprema-tunela/ (13. 12. 2018.)

svn.vsp.tu-berlin.de/repos/public-svn/lehre/veranstaltungen/ss_2011/0533__050/telematik.pdf(12. 12. 2018.) 


\title{
USING DIAGRAMS IN THE REPRESENTATION OF DATA MANAGEMENT ON MOTORWAYS
}

\author{
Josip Jerčić
}

Bacc. Ing. Traff., Ceste Rijeka d.o.o., Kukuljanovo 377, 51223 Škrljevo, Croatia; e-mail: jercicjosip@gmail.com

\section{Mirta Mataija}

MSc, Lecturer, Polytechnic of Rijeka, Trpimirova 2/V, 51000 Rijeka, Croatia; e-mail: mirta.mataija@veleri.hr

\begin{abstract}
Motorways in the Republic of Croatia are equipped with the most modern systems for managing and controlling traffic. Monitoring and traffic management system on motorways are carried out constantly 24 hours a day from the maintenance and traffic control centers that are located along the individual motorway sections. Motorway traffic control centers, using modern Intelligent Transport Systems, constantly and in real-time monitor the state of the motorways and warn and prepare motorway users for all the extraordinary situations that motorway users might encounter. Using the camera and the video surveillance system deployed by motorways, operators have an insight into the current state of the motorway section, primarily by means of a traffic accident detection camera, driving in the opposite direction, traffic jam, etc. Numerous meteorological stations along the highway also collect and process data related to weather conditions on the highway and using these data to warn motorway users of weather conditions expected on a motorway. In this paper, the information management system on motorways is described using graphs. The graph theory allows displaying the flow of information essential to increase security and to address emission and congestion issues. The flow of information between the sensor system on one side, and the operator in the maintenance and control centers on the other, and the variable traffic signs system on the third side is represented by graphs. Timely information of traffic participants on changing meteorological conditions through variable signs is crucial to ensure safe traffic on motorways.
\end{abstract}

Key words: motorway, a center for sustainable traffic control, traffic centers, road traffic station, variable traffic signalization, traffic safety, traffic management, tunnels, meteorological stations 